\title{
Temporal variations in metallothionein concentration and subcellular distribution of metals in gills and digestive glands of the oyster Crassostrea angulata
}

\author{
CHIARA TROMBINI ${ }^{1}$, ELENA FABBRI ${ }^{2}$ and JULIÁN BLASCO ${ }^{1}$ \\ ${ }^{1}$ Instituto de Ciencias Marinas de Andalucía (CSIC), Campus Río San Pedro, 11510 Puerto Real, Cádiz, Spain. \\ E-mail: julian.blasco@icman.csic.es \\ ${ }^{2}$ Interdisciplinary Centre for Research in Environmental Sciences (CIRSA), University of Bologna, \\ Campus of Ravenna, Italy.
}

\begin{abstract}
SUMMARY: The metallothionein levels and metal concentrations in whole body, digestive gland and gills of Crassostrea angulata were analyzed in field samples collected from the River Guadalquivir estuary over several years following a mining waste spill upstream. The subcellular distribution of metals was analyzed to determine the mechanisms involved in the detoxification process. The highest metallothionein levels were reported in the digestive gland shortly after the mining contamination event. In this organ, metals are stored preferentially in the non-cytosolic fraction when increased bioaccumulation takes place. In the cytosol of the gills, metals are associated with metallothionein, whereas in the digestive gland, the distribution of metals between metallothioneins and high molecular weight proteins is similar. Metallothionein variation cannot be explained by metals alone; other abiotic factors must be taken into account. In order to use metallothionein as a metal exposure biomarker in field studies, natural variability needs to be taken into account for the correct interpretation of results.
\end{abstract}

Keywords: metallothionein, metals, subcellular distribution, River Guadalquivir estuary, mining accident, Crassostrea angulata.

RESUMEN: VARIACIÓN TEMPORAL DE LA CONCENTRACIÓN DE METALOTIONEÍNAS Y DISTRIBUCIÓN SUBCELULAR DE METALES EN BRANQUIAS Y GLÁNDULA DIGESTIVA DEL OSTRON CRASSOSTREA ANGULATA. - Los niveles de metalotioneínas y las concentración de metales en cuerpo total, glándula digestiva y branquias de Crassostrea angulata han sido analizados en muestras de campo recogidas en el estuario del Guadalquivir durante varios años después de un accidente minero. La distribución subcelular de metales se analizó con el fin de conocer los mecanismos implicados en los procesos de detoxificación. Los niveles más elevados de metalotioneínas se hallaron en la glándula digestiva de muestras recogidas después del accidente minero. En este órgano, los metales se almacenan preferencialmente en la fracción no citosólica cuando la bioacumulación aumenta. En el citosol de las branquias, los metales se hallan asociados a las metalotioneínas, mientras que en la glándula digestiva, éstos se encuentran distribuidos de manera similar entre las metalotioneínas y las proteínas de alto peso molecular. La variación de la concentración de metalotioneínas no puede ser explicada sólo en base a las concentraciones de metales, y otros factores abióticos pueden ser responsables del porcentaje de varianza no explicado. Por ello, el empleo de la concentración de metalotioneína como biomarcador de exposición de metales en Crassostrea angulata debe ser considerado con precaución y el conocimiento de la variabilidad natural deber ser tenido en cuenta para una correcta interpretación de los resultados.

Palabras clave: metalotioneinas, metales, distribución subcelular, estuario del río Guadalquivir, accidente minero, Crassostrea angulata.

\section{INTRODUCTION}

Coastal ecosystems of estuaries are vulnerable because they are subjected to both diffusive and periodic contamination from agricultural, industrial and urban activities. The Guadalquivir is the principal river in the SW of the Iberian Peninsula and its estuary is an important area in which many marine species are reared. This river has been impacted by metal contamination as a result of agricultural and mining activities and 
urban sewage discharge (Blasco et al., 1999; GarcíaLuque et al., 2003; Grimalt et al., 1999).

Metallothionein-like proteins (MTLPs) are metalloproteins, which play a role in the homeostasis of the essential metals $\mathrm{Zn}$ and $\mathrm{Cu}$ and are involved in detoxification processes for non-essential trace metals such as $\mathrm{Ag}, \mathrm{Cd}$ and $\mathrm{Hg}$ (Mason and Jenkins, 1995; Mouneyrac et al., 2001). These proteins are ubiquitous in vertebrates, invertebrates, microorganisms and plants (in the latter, a second type of metal-binding protein which participates in detoxification of heavy metals is phytochelatin, also very often called class III metallothionein) (Tomaszewska, 2002). The known induction of MTLP synthesis in aquatic organisms (fish, crustaceans and molluscs) exposed to an environment contaminated by metals has led to the suggestion that the determination of MTLP levels could represent a suitable monitoring procedure for assessing metal contamination in the marine environment (George and Olsson, 1994; Langston et al., 1998; Cosson, 2000; Cosson and Amiard, 2000; Cajaraville et al., 2000). Bivalves, mainly mussels (George and Olsson 1994) and oysters (Silva et al., 2001, Mouneyrac et al., 1998), are considered the most appropriate species for use in monitoring the quality of coastal and estuarine waters and are recommended in numerous pollution monitoring programmes in Europe and the USA (the North Sea Task Force Monitoring Master Plan, the NOAA's National Status and Trends Programme and the Mediterranean Biomonitoring Programme). However, numerous studies have shown that levels of MTPLs are influenced by several factors of an environmental (salinity, season, location in the intertidal zone, etc.) and biological (sexual maturity, weight, etc.) nature (Hamza-Chaffay et al., 1999; Mouneyrac et al., 1998). This is especially relevant in field studies where changes in the concentration of MTPLs due to metal contamination need to be distinguished from those related to natural variations.

In this study concentrations of MTLP and metals ( $\mathrm{Cd}, \mathrm{Co}, \mathrm{Cu}, \mathrm{Fe}, \mathrm{Mn}, \mathrm{Ni}, \mathrm{Zn}$ ) were studied in the whole body, gills and digestive gland of the oyster Crassostrea angulata in the Guadalquivir estuary. Temporal variations in these concentrations were examined over a period of one year (from immediately after a mining accident) to evaluate seasonal changes. Finally, subcellular partitioning (pellet, cytosol and heat-stable fraction including MTLP) of the metals was studied to obtain information on the cellular distribution of metals and metallothionein induction.

\section{MATERIALS AND METHODS}

\section{Sampling and fraction preparation}

Oysters (Crassostrea angulata) were collected monthly over a period of one year (from April 1998 to April 1999) at two sampling sites in the Guadalquivir estuary, Punta Montijo (M) and Las Piletas (P). The sampling stations, shown in Figure 1, are relatively

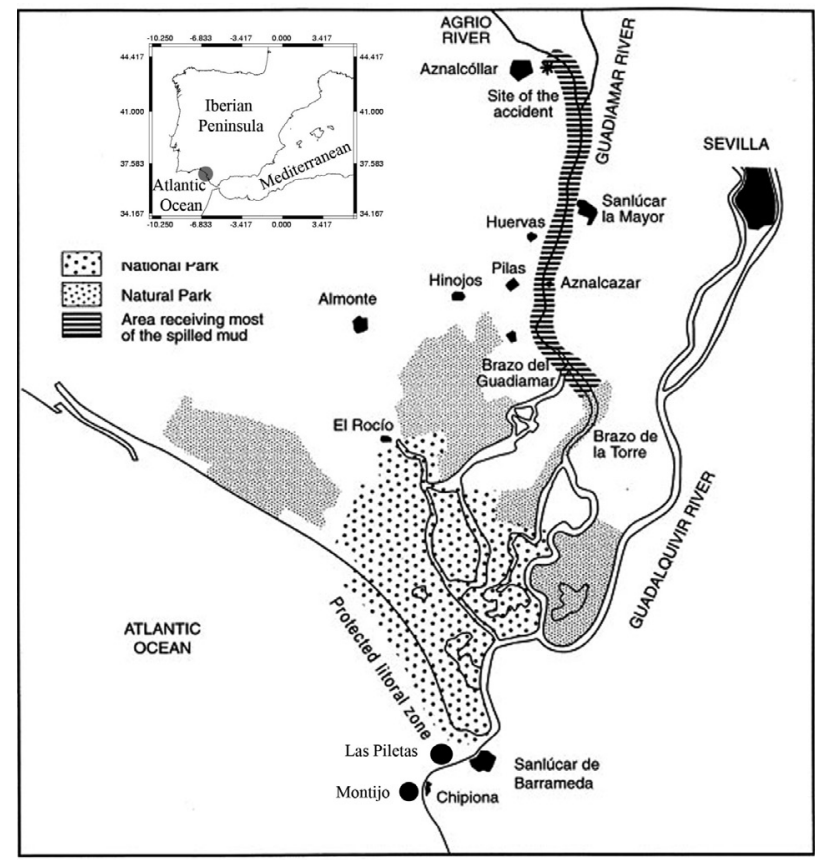

FIG. 1. - Map of Doñana Park and surrounding areas including Aznalcollar mine. Both sampling station were indicated with black circles (Las Piletas $36^{\circ} 47^{\prime} 06.35^{\prime}$ 'N , 6 ${ }^{\circ} 22^{\prime} 27.57^{\prime}$ 'W, Montijo $\left.36^{\circ} 45^{\prime} 41.01^{\prime} \mathrm{N}, 6^{\circ} 24^{\prime} 36.33^{\prime \prime} \mathrm{W}\right)$.

close to each other but are situated in the intertidal and subtidal zone, respectively. At station M, samples were also collected in 1999, 2000 and 2001. Sampling was carried out twice yearly, in the spring and autumn seasons of each year. Oysters collected in the field were transported to the laboratory and depurated for $48 \mathrm{~h}$ in seawater before being dissected into gills and digestive gland. The individual tissues were kept at $-80^{\circ} \mathrm{C}$ until analysis. Tissues were homogenized in ice-cold $100 \mathrm{mM}$ Tris $\mathrm{HCl} / \mathrm{Base}\left(\mathrm{pH} 8.1\right.$ at $\left.4^{\circ} \mathrm{C}\right), 1 \mathrm{mM}$ DTT and Protease Inhibitor Cocktail (SIGMA P2714). The ratio of buffer solution to the fresh tissue weight was 1:5 $(\mathrm{v} / \mathrm{w})$ for digestive gland and 1:3 $(\mathrm{v} / \mathrm{w})$ for gills. The homogenate was subsequently centrifuged (50000 $\mathrm{g}$ for $120 \mathrm{~min}$ at $4^{\circ} \mathrm{C}$ ). The supernatant (S1) was separated from the pellet $(\mathrm{P} 1)$, heat-treated at $95^{\circ} \mathrm{C}$ for $10 \mathrm{~min}$ and centrifuged $\left(10000 \mathrm{~g}\right.$ for $15 \mathrm{~min}$ at $4^{\circ} \mathrm{C}$ ) (Dignam, 1990) to separate heat-stable compounds including MTLP (supernatant S2) from heat-unstable compounds (pellet P2). All the procedures were carried out at $-4^{\circ} \mathrm{C}$ to avoid protein degradation. All glassware used was previously washed in $\mathrm{HNO}_{3}$ at $10 \%$ for 24 hours, rinsed with MilliQ water and dried. The water used in all procedures (solution preparation and material washing) was pure water obtained using a MilliQ purification system.

\section{MTLP analysis}

The amount of MTLP was determined in the heattreated cytosol (S2) by differential pulse polarographic analysis, according to the procedure described by Olaf- 
son and Olsson (1991). A MetrohmTrace Analyzer with mercury drop electrode (SMDE) was used. The temperature of the cell was maintained at $7^{\circ} \mathrm{C}$. The standard addition method was used for calibration with rabbit metallothionein I and II (Sigma M7641) in the absence of purified metallothionein from oyster. Results are expressed as $\mu \mathrm{g}$ MTLP/g dry weight of homogenized tissue.

\section{Metal analysis}

Metal analyses were performed on lyophilized tissue (whole body) and subsamples of the homogenate (S1, P1 and P2 fractions for gills and digestive gland) previously digested with suprapure $\mathrm{HNO}_{3}$ and $\mathrm{H}_{2} \mathrm{O}_{2}$ according to an adaptation of the procedure of Amiard et al. (1987). Metal concentrations (Cd, Co, Cu, Fe, Mn, $\mathrm{Ni}, \mathrm{Zn}$ ) were determined using ICP-OES (Perkin Elmer 2000 DV). The quality of results was checked using certified reference material (Mytilus edulis EU BCR CRM278R). Metal concentrations ( $\mu \mathrm{g} / \mathrm{g}$ dry weight \pm SD) obtained showed a good agreement with certified values. All metal concentrations are expressed as $\mu \mathrm{g} / \mathrm{g}$ dry weight tissue.

\section{Statistical analysis}

One-way ANOVA, post-test for mean comparison (Student $t$ test or Mann-Whitney test) and regression analysis (linear or multiple) were carried out using the SigmaStat 3.1 program. Metal contents were first normalized in order to standardize the different concentration ranges. The natural variables $x_{\mathrm{i}}$ were transformed into coded variables $X_{i}$.

$$
M T=\alpha_{0}+\sum_{i=1}^{n} \alpha_{i} X_{i}
$$

$\mathrm{X}_{\mathrm{i}} \max =+1$ for the maximum value of the variable, and $X_{i} \min =-1$ for the minimum value. The transformation of natural quantitative variables $(\mathrm{Cu}, \mathrm{Mn}, \mathrm{Zn}$, $\mathrm{Cd}, \mathrm{Ni}$ and $\mathrm{Co}$ ) to coded variables is given by the following equation (Bebianno and Serafim, 2002):

$$
X_{i}=\frac{x_{i}-\left(x_{i \max }+x_{i \min }\right) / 2}{\left(x_{i \max }-x_{i \min }\right) / 2}
$$

where $x_{\mathrm{i} \min }=$ the lowest value of the natural variable, and $x_{\mathrm{i} \text { max }}=$ the highest value of natural variable.

\section{RESULTS}

\section{Temporal variation in MTLP and metal concentrations}

The temporal evolution of MTLP concentrations in gills and digestive gland for oysters from each of the two sampling stations is illustrated in Figure 2. MTLP concentrations for station $\mathrm{M}$ were higher than those for
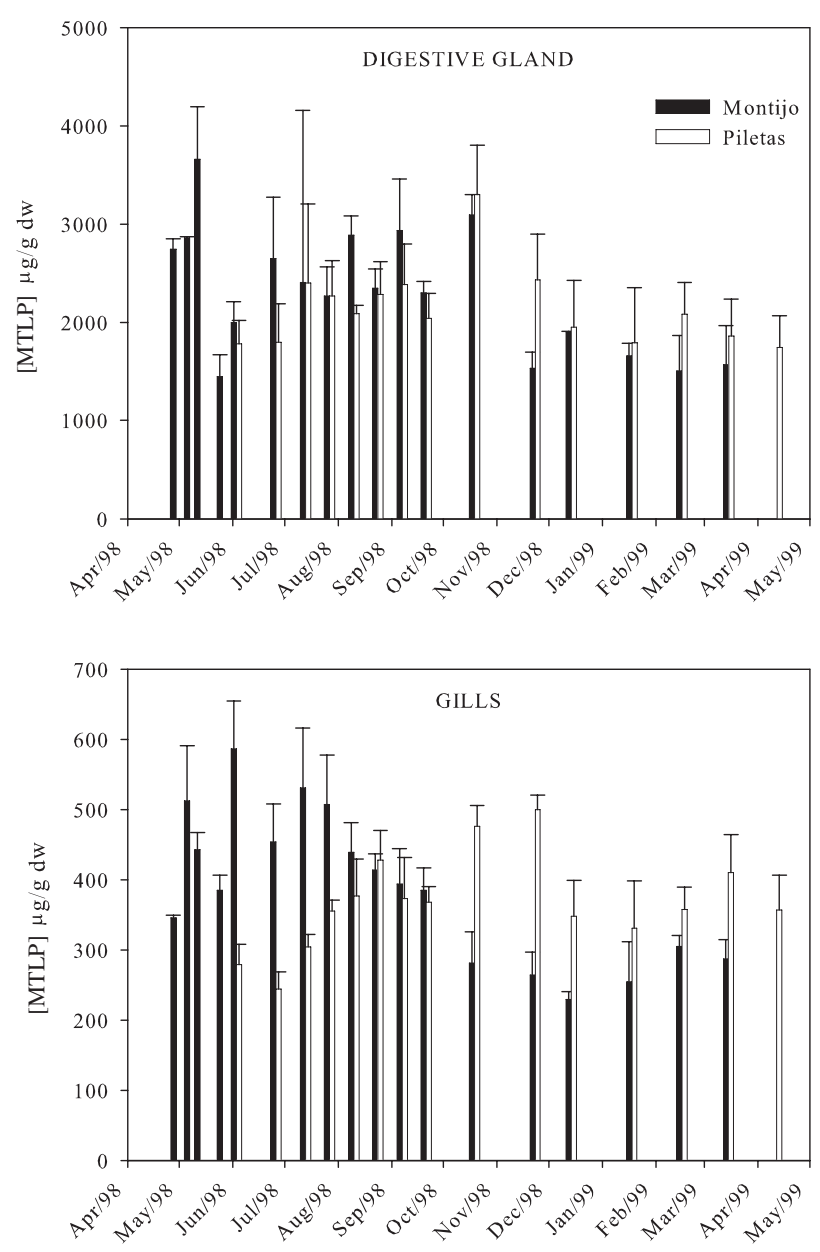

FIG. 2. - Seasonal evolution of MTLP concentrations in digestive gland and gills of oysters collected at both stations (Montijo, black columns; Piletas, white columns). MTLP values are expressed in $\mu \mathrm{g} / \mathrm{g}$ dry weight.

station $\mathrm{P}$ in the first six months (April- September) for both tissues; on the other hand, MTLP concentrations for station $\mathrm{P}$ were higher than those for the station $\mathrm{M}$ in the second six months (October-March). Even so, no significant differences were detected between the two locations. Furthermore, there was no statistically significant difference in the seasonal trend between the two stations. The highest MTLP concentrations were found in the digestive gland (nearly six times higher than in the gills) and there were significant differences between tissues $(P<0.001)$. Overall, the values of MTLP concentrations recorded in 1998 were higher than those recorded in the next year (the mining spill occurred on 25 April 1998). For the digestive gland the highest value was in May 1998 (3659.4 \pm 531.4 $\mu \mathrm{g} / \mathrm{g}$ dry weight) and for gills in June 1998 (586.4 \pm $68.1 \mu \mathrm{g} / \mathrm{g}$ dry weight). MTLP concentrations in the digestive gland decreased considerably in June and tended to increase in the following months to reach a maximum in October-November (this trend was less evident in gills). MTLP levels in gills were higher in 

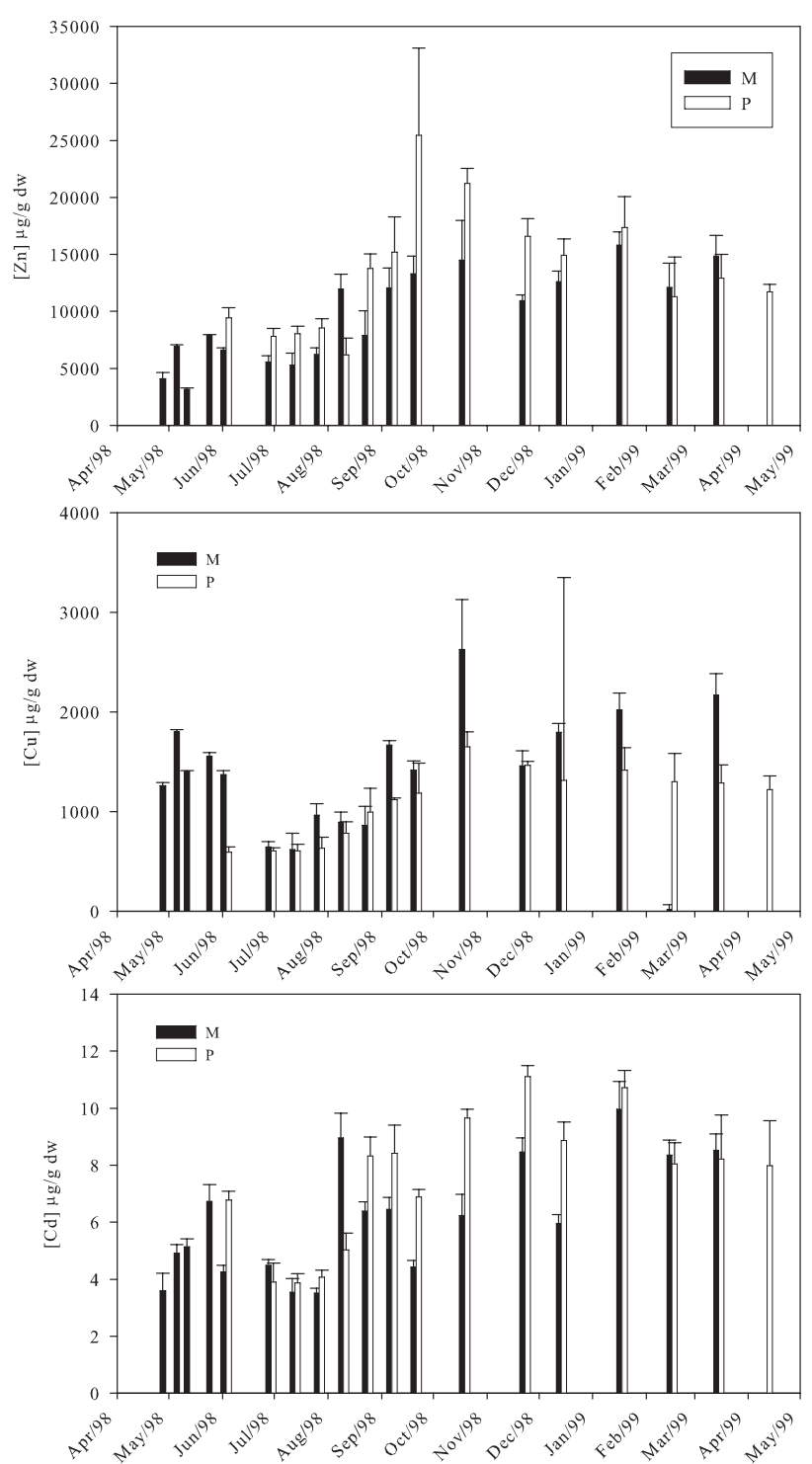

FIG. 3. - Temporal variation (April 1998-April 1999) of $\mathrm{Zn}, \mathrm{Cu}$ and $\mathrm{Cd}$ concentrations $(\mu \mathrm{g} / \mathrm{g}$ dry weight) in the whole body of oyster collected at Montijo (black columns) and Piletas (white columns).

the spring-summer period (from May to October) than in the remaining six months. In both tissues, the levels for April-May 1999 were lower than during the same period in 1998.

Metal concentrations in whole body of $C$. angulata collected at the two sampling stations from April 1998 to April 1999 are shown in Figures 3 ( $\mathrm{Zn}, \mathrm{Cu}$ and $\mathrm{Cd}$ ) and $4(\mathrm{Mn}$ and $\mathrm{Fe})$. The differences between stations $\mathrm{M}$ and $\mathrm{P}$ were not statistically significant. As with MTLP, high concentrations of $\mathrm{Cu}, \mathrm{Cd}$ and $\mathrm{Mn}$ were recorded in May 1998, followed by a decrease in July; this trend, however, was not evident for $\mathrm{Zn}$ and Fe. From July, levels of all the metals showed a tendency to increase, reaching maximum values in September or October (depending on the metal). From October, the levels of $\mathrm{Mn}$ decreased, while $\mathrm{Cd}$ and $\mathrm{Cu}$ levels
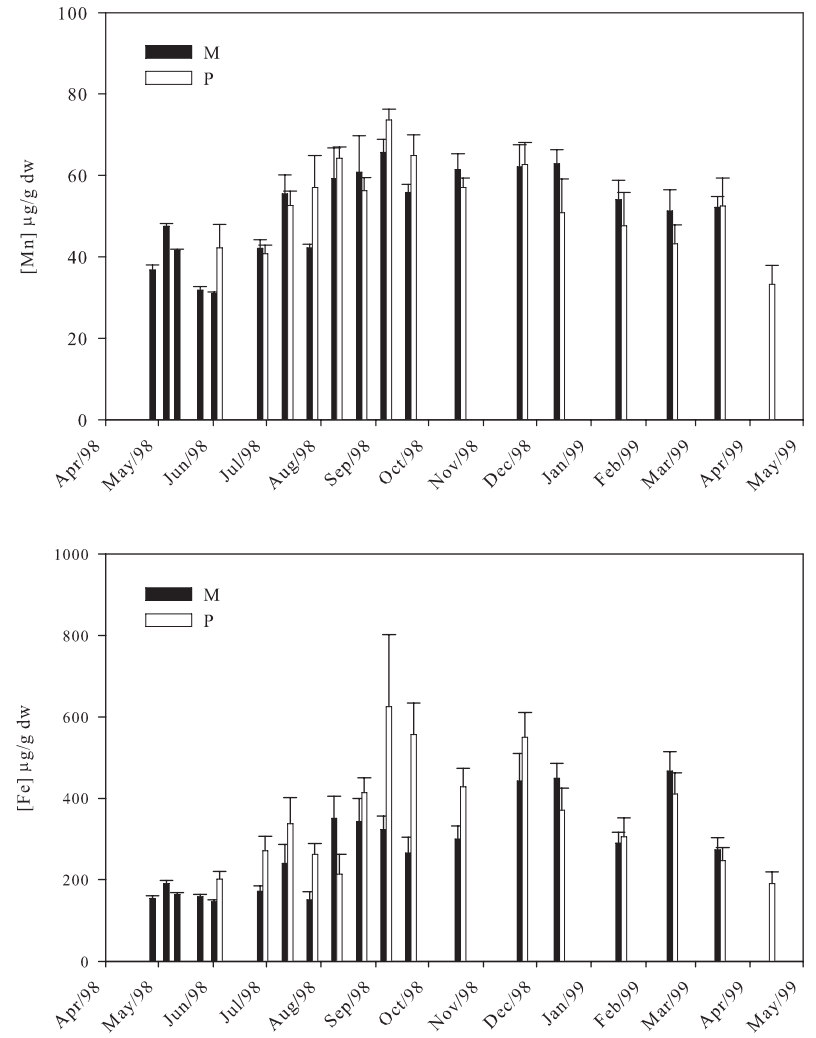

Fig. 4. - Temporal variation (April 1998-April 1999) of Mn and Fe concentrations ( $\mu \mathrm{g} / \mathrm{g}$ dry weight) in the whole body of oyster collected at Montijo (black columns) and Piletas (white columns).

remained unchanged. At both stations, $\mathrm{Zn}$ was the metal that showed the highest concentrations in whole body and in the two tissues (Table 1). The other metals were present in lower concentrations, according to the sequence $\mathrm{Cu}>\mathrm{Fe}>\mathrm{Mn}>\mathrm{Cd}$. Seasonal changes for metal concentrations in digestive gland from 1998 to 2001 at the "Montijo" sampling station are plotted in Figure 5. $\mathrm{Zn}, \mathrm{Mn}, \mathrm{Cd}$ and $\mathrm{Ni}$ increased in the year of the accident from April to October, while $\mathrm{Cu}$ and $\mathrm{Fe}$ did not show significant changes. Data for April 1998 for Co are not available but an increase in concentration was observed from October 1998 to April 1999. Metal concentrations in 1998 were generally lower than in the following years.

\section{Subcellular distribution of metals and relationship to MTLP}

Figure 6 shows, for $\mathrm{Cu}$ and $\mathrm{Mn}$, the relationship between total metal concentration $(\mathrm{S} 1+\mathrm{P} 1)$ and the concentration in cytosolic (S1) and non-cytosolic fractions (P1) in digestive gland and gills. The parameters of the equations of the linear regressions between soluble (cytosolic) and insoluble (non-cytosolic) metal versus total metal are shown in Table 2 for all the metals. In the digestive gland, with increasing total concentrations, metals tend to be stored in the insoluble fraction, since it can be observed that the slope of the equation is always significantly higher $(P<0.001)$ for this fraction 
TABLE 1. - Average and range (in brackets) ( $\mu \mathrm{g} / \mathrm{g}$ dry weight) of metal concentrations in the digestive gland and gills of oysters from the two stations. These data represent the sum of S1 and P1. No data for $\mathrm{Zn}$ are available for the Piletas station. DG: digestive gland; G: gills; n.a.: not available.

\begin{tabular}{ccccccccc}
\hline Station & Tissue & $\mathrm{Zn}$ & $\mathrm{Cu}$ & $\mathrm{Cd}$ & $\mathrm{Mn}$ & $\mathrm{Fe}$ & $\mathrm{Ni}$ & $\mathrm{Co}$ \\
\hline Montijo & $\mathrm{DG}$ & 7213 & 1176 & 7.5 & 19 & 386 & 4.3 & 1.6 \\
& & $(1676-16548)$ & $(622-1910)$ & $(4.4-11.6)$ & $(14-23)$ & $(180-805)$ & $(1.1-8.1)$ & $(0.4-4.0)$ \\
& $\mathrm{G}$ & 6128 & 1152 & 3.44 & 39 & 253 & 4.7 & 1.2 \\
& & $(1931-10398)$ & $(568-1692)$ & $(1.9-7.5)$ & $(24-54)$ & $(118-492)$ & $(2.8-6.8)$ & $(0.3-2.5)$ \\
Piletas & DG & n.a. & 998 & 13.1 & 19 & 612 & 2.8 & 2.5 \\
& & & $(465-1803)$ & $(5.3-30.6)$ & $(13-29)$ & $(248-1627)$ & $(1.7-3.6)$ & $(0.6-7.9)$ \\
& G & n.a. & 925 & 5.7 & 32 & 364 & 3.6 & 1.9 \\
& & & $(472-1285)$ & $(2.5-12.5)$ & $(25-53)$ & $(136-908)$ & $(2.1-4.5)$ & $(0.4-4.4)$ \\
\hline
\end{tabular}
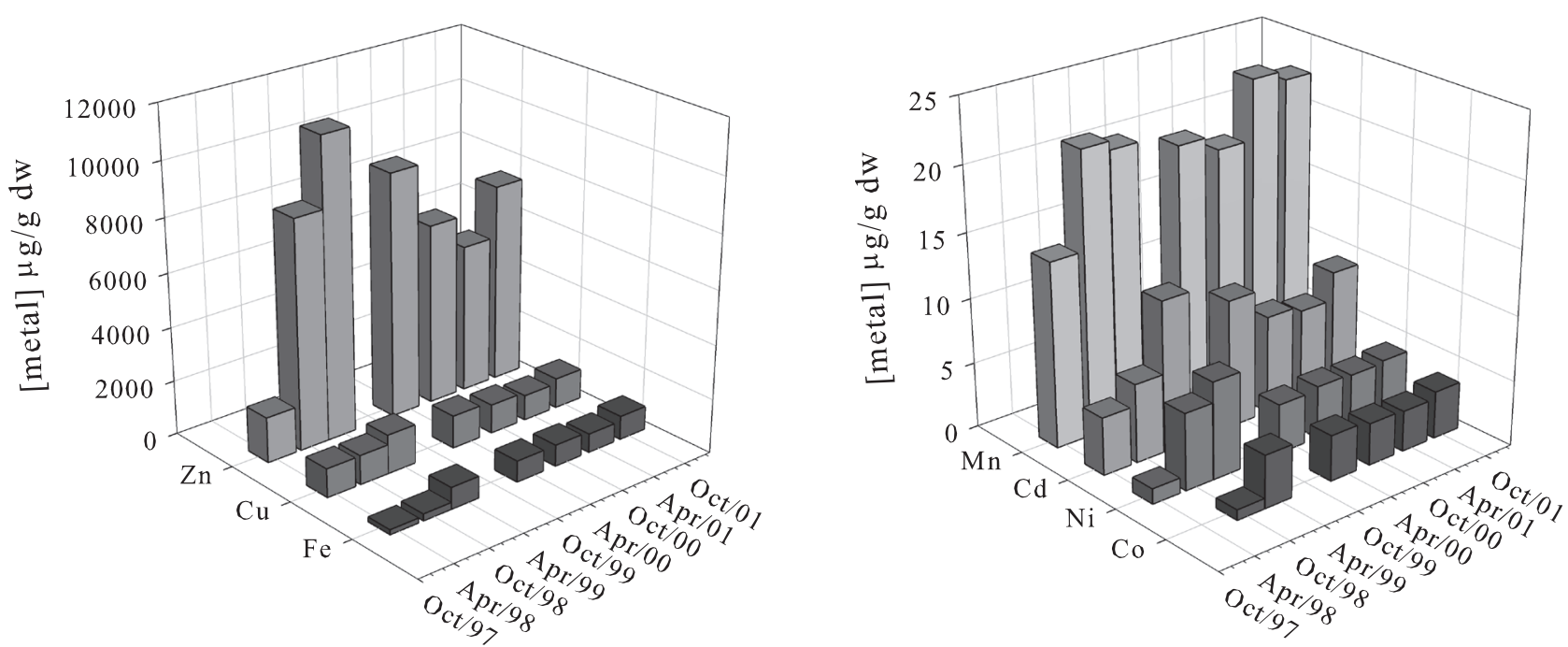

FIG. 5. - Temporal evolution (April, October) in the years 1999, 2000 and 2001 for metal concentrations ( $\mu$ g/g dry weight) in digestive gland of oysters from Montijo.

TABLE 2. - Soluble (S1) and insoluble (P1) fractions vs. total metal contents in digestive gland and gill of $C$. angulata: slope, intercept and correlation coefficients of regression straight lines. $(\mathrm{n}=36$, for $\mathrm{Zn} \mathrm{n}=21$ ).

\begin{tabular}{|c|c|c|c|c|c|c|c|}
\hline \multirow[t]{2}{*}{ Metals } & \multirow[t]{2}{*}{ Fraction } & \multicolumn{3}{|c|}{ Digestive gland } & \multicolumn{3}{|c|}{ Gills } \\
\hline & & Slope & Intercept & $r$ & Slope & Intercept & $r$ \\
\hline $\mathrm{Cu}$ & P1 & 0.853 & 65.735 & $0.885^{*}$ & 0.826 & 98647 & $0.824 *$ \\
\hline $\mathrm{Cu}$ & S1 & 0.066 & 40.952 & 0.267 & 0.169 & -78.096 & 0.313 \\
\hline $\mathrm{Zn}$ & P1 & 0.804 & -370.196 & $0.830 *$ & 0.821 & -822.72 & $0.786^{*}$ \\
\hline $\mathrm{Zn}$ & S1 & 0.173 & 699.875 & $0.724 *$ & 0.134 & 1053.49 & 0.608 \\
\hline $\mathrm{Mn}$ & P1 & 0.872 & 1.911 & $0.993^{*}$ & 0.435 & 6.307 & $0.830 *$ \\
\hline $\mathrm{Mn}$ & S1 & 0.128 & 0.217 & $0.771 *$ & 0.408 & -0.691 & $0.754 *$ \\
\hline $\mathrm{Fe}$ & P1 & 0.985 & -48.171 & $0.998 *$ & 0.996 & -22.767 & $0.996 *$ \\
\hline $\mathrm{Fe}$ & S1 & 0.013 & 48.297 & 0.307 & 0.015 & 24.032 & 0.439 \\
\hline $\mathrm{Cd}$ & P1 & 0.919 & -0.073 & $0.994 *$ & 0.960 & -0.142 & $0.985^{*}$ \\
\hline $\mathrm{Cd}$ & S1 & 0.069 & 0.223 & $0.769^{*}$ & 0.048 & 0.257 & 0.383 \\
\hline $\mathrm{Ni}$ & P1 & 0.846 & -0.596 & $0.943^{*}$ & 0.688 & -0.598 & $0.861^{*}$ \\
\hline $\mathrm{Ni}$ & S1 & 0.215 & 0.429 & $0.713^{*}$ & 0.348 & 0.496 & $0.708^{*}$ \\
\hline Co & P1 & 0.998 & -0.356 & $0.999 *$ & 1.002 & -0.204 & $0.996^{*}$ \\
\hline Co & S1 & 0.001 & 0.364 & 0.007 & 0.015 & 0.198 & 0.214 \\
\hline
\end{tabular}

* significant at the $99 \%$ level

than for the soluble fraction (Table 2). In the gills, only for $\mathrm{Cu}, \mathrm{Zn}, \mathrm{Fe}, \mathrm{Co}$ and $\mathrm{Cd}$ is the slope for the equation consistently higher for the insoluble fraction (Table 2) whereas for $\mathrm{Ni}$ and $\mathrm{Mn}$, as shown by the parameters of the equation, the metal tends to accumulate equally in both $\mathrm{S} 1$ and P1.

Figure 7 shows the relationship between metal contents in S2 (heat-stable proteins including MTLPs) and 

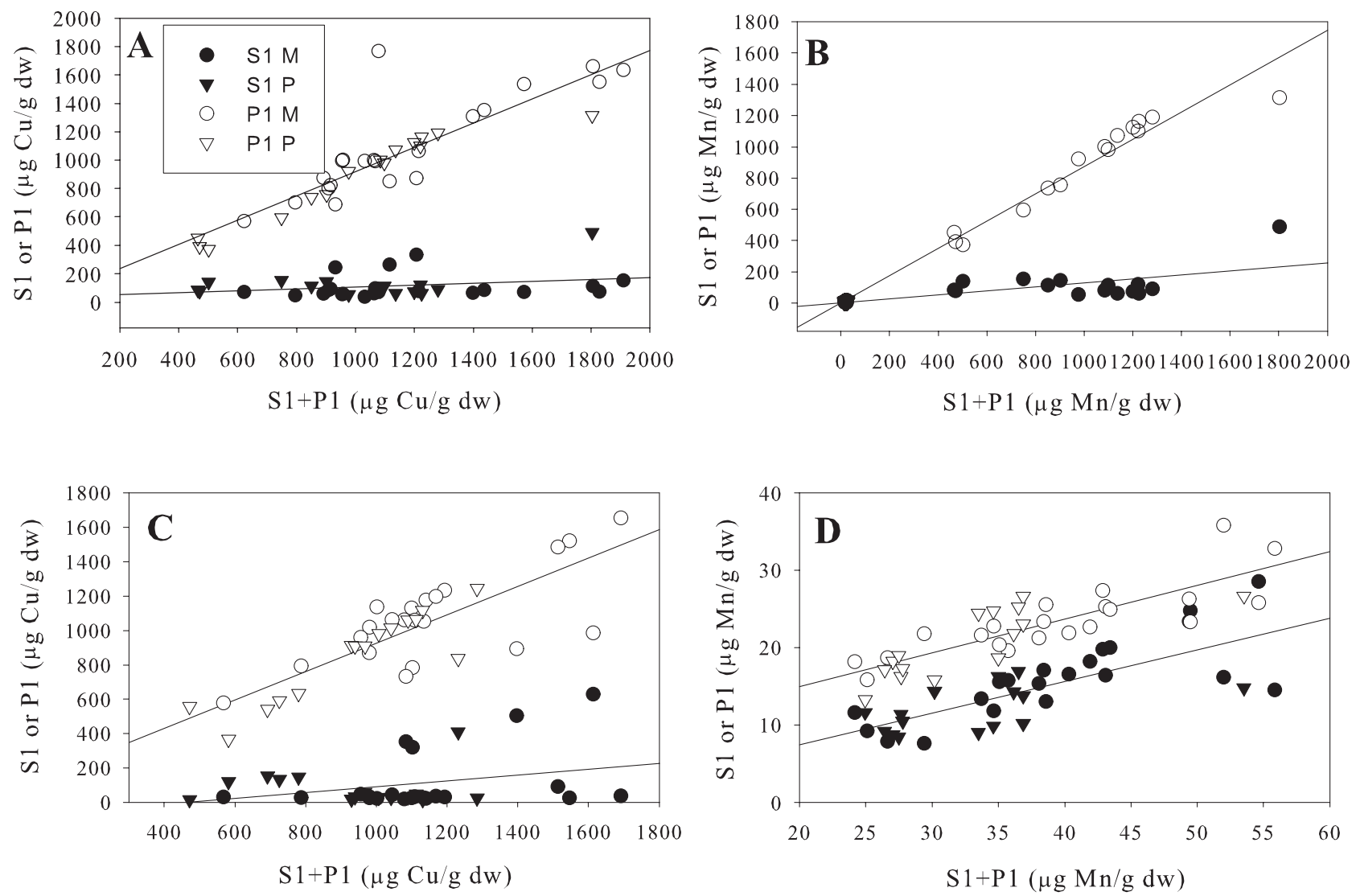

FIG. 6. - Soluble (S1) and insoluble (P1) fractions vs total metal content (S1+P1) for Cu and $\mathrm{Mn}$ in the digestive gland (A, B) and gills (C, D) of $C$. angulata. Values for both sampling stations ( $\mathrm{M}=$ Montijo, $\mathrm{P}=\mathrm{Piletas}$ ) were considered together. Metal concentrations are expressed in $\mu \mathrm{g} / \mathrm{g}$ dry weight. The parameters of the straight line equations are shown in Table 2.

TABLE 3. - Parameters of the equation* MTLP concentration $=\mathrm{f}$ (metal concentration) for metals in the soluble S1 fraction at two sites, Montijo and Piletas, in the Guadalquivir estuary. Only those metals significantly related to MTLP concentration $(P<0.005)$ are included in this table. Number of samples: Montijo=17, Piletas=14. There are no data for $\mathrm{Zn}$ for the Piletas station.

\begin{tabular}{|c|c|c|c|c|c|c|c|c|c|c|}
\hline Site & Organ & \multicolumn{7}{|c|}{ Metals (regression coefficients $\alpha_{1}, \alpha_{2}, \alpha_{3}, \ldots$ ) } & Constant $\left(\alpha_{0}\right)$ & $\mathrm{R}_{\text {Adj }}^{2}$ \\
\hline Montijo & Digestive gland & n.r. & $\begin{array}{c}742.652 \\
(\mathrm{P}=0.008)\end{array}$ & $\begin{array}{l}1444.295 \\
(\mathrm{P}<0.001)\end{array}$ & n.r. & $\begin{array}{l}-618.539 \\
(\mathrm{P}=0.020)\end{array}$ & $\begin{array}{l}-726.876 \\
(\mathrm{P}=0.025)\end{array}$ & $\begin{array}{l}-932.193 \\
(\mathrm{P}=0.050)\end{array}$ & 2333.773 & 0.510 \\
\hline & Gills & n.r. & $\begin{array}{c}96.952 \\
(\mathrm{P}=0.017)\end{array}$ & $\begin{array}{c}120.241 \\
(\mathrm{P}=0.007)\end{array}$ & $\begin{array}{l}-187.568 \\
(\mathrm{P}<0.001)\end{array}$ & n.r. & n.r. & n.r. & 478.247 & 0.507 \\
\hline \multirow[t]{2}{*}{ Piletas } & Digestive gland & $\begin{array}{l}-653.894 \\
(\mathrm{P}=0.036)\end{array}$ & $\begin{array}{c}616.187 \\
(\mathrm{P}=0.033)\end{array}$ & n.r. & n.a. & $\begin{array}{c}349.800 \\
(\mathrm{P}=0.014)\end{array}$ & $\begin{array}{l}-127.716 \\
(\mathrm{P}=0.339)\end{array}$ & $\begin{array}{c}445.613 \\
(\mathrm{P}=0.004)\end{array}$ & 1953.901 & 0.694 \\
\hline & Gills & n.r. & n.r. & n.r. & n.a. & $\begin{array}{c}61.117 \\
(\mathrm{P}=0.063)\end{array}$ & n.r. & n.r. & 365.201 & 0.183 \\
\hline
\end{tabular}

$\mathrm{P}=$ probability for a significant correlation between MTLP and soluble metal concentration based on $t$ test.

n.r. $=$ not reported.

P2 (proteins and other molecules that precipitate during heat-treatment) in the gills. In this tissue, when metal concentrations in the cytosolic fraction (S1) are low, the metals are distributed equally between S2 and P2 fractions. When cytosolic concentration of the metal increases, the metal is binding to the thermostable proteins contained in the $\mathrm{S} 2$ fraction. The amount of metal present in the $\mathrm{P} 2$ fraction remains unchanged, except for $\mathrm{Fe}$ and $\mathrm{Co}$ where a negative slope is reported for both metals. In the digestive gland, only Fe, Mn and Co show a tendency to bind to the S2 fraction, when the metal concentration increases in the $\mathrm{S} 1$ fraction. However, $\mathrm{Cu}, \mathrm{Cd}$ and $\mathrm{Ni}$ concentrations increase in both fractions (but without significant differences between $\mathrm{S} 2$ and $\mathrm{P} 2$ ).

The relationship between MTLP and metal concentrations (for $\mathrm{Cd}, \mathrm{Co}, \mathrm{Cu}, \mathrm{Fe}, \mathrm{Mn}, \mathrm{Ni}$ and $\mathrm{Zn}$ ) was determined using multiple regression analysis (best subset regression). Independent variables were standardized and expressed according to the following function: 

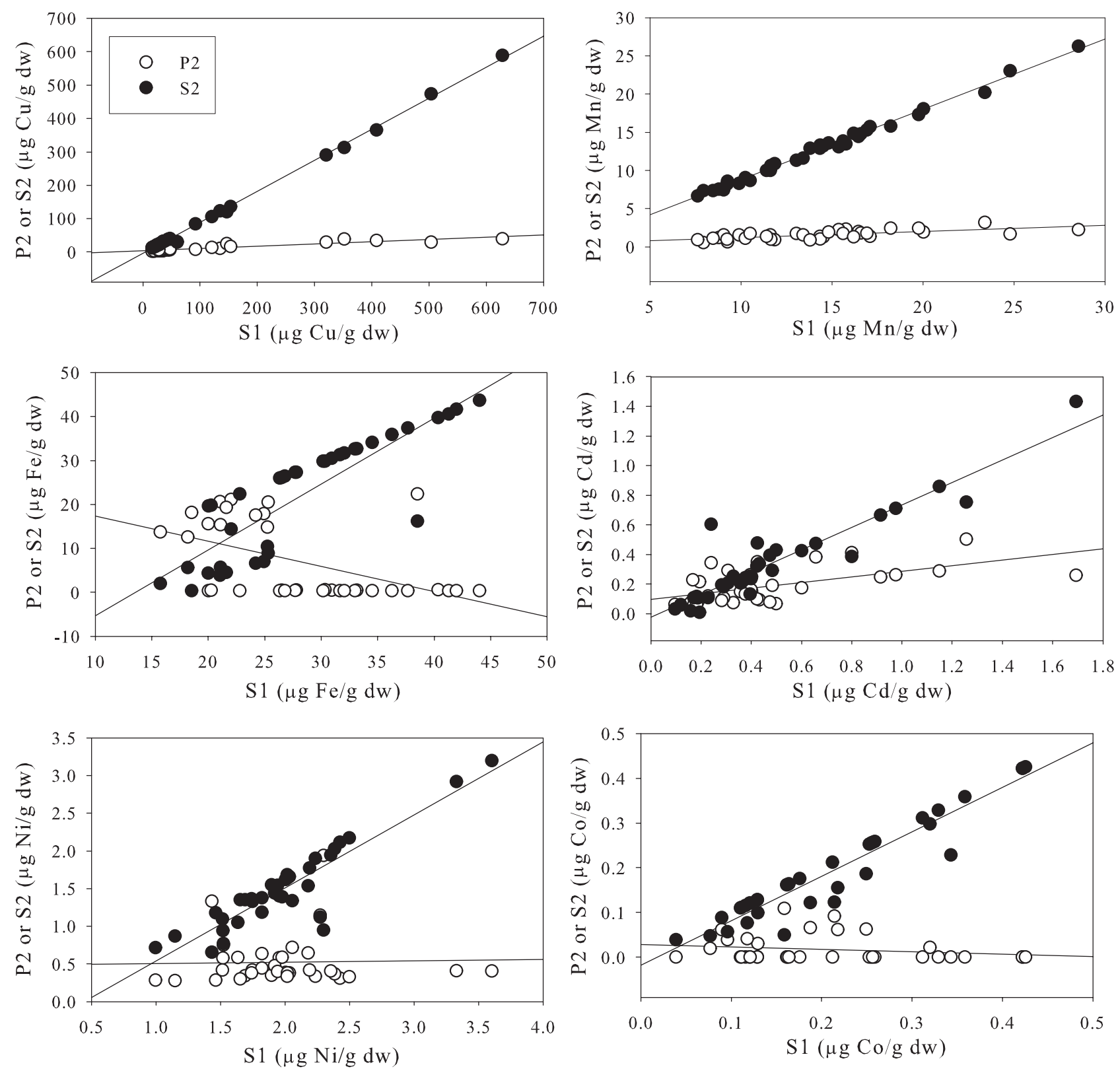

Fig. 7. Relationship between metal content in $\mathrm{P} 2$ and $\mathrm{S} 2$ fractions and total metal in cytosol of gill. Data for $\mathrm{Zn}$ not are available. For each metal values relative to both stations are considered together. Metal concentrations are expressed in $\mu \mathrm{g} / \mathrm{g}$ dry weight.

MTLP $=f(\mathrm{Cd}, \mathrm{Co}, \mathrm{Cu}, \mathrm{Fe}, \mathrm{Mn}, \mathrm{Ni}, \mathrm{Zn})$. This model was applied for the digestive gland and gills separately. Because MTLP is a cytosolic heat-stable protein, it seems appropriate to consider the relationship between MTLP concentration in a particular type of tissue, and metal concentration in the supernatant obtained after heat-denaturation of the cytosol (S2). However, during heating, the distribution of metals among cytosolic compounds may be modified (Bragigand and Berthet, 2003). Consequently, in the present study, the relationship between MTLP concentration and metal content in the supernatant before heat treatment (S1) was examined. The parameters for the regression are summarized in Table 3. At station M, Cd, Mn, Fe, Ni and Co together explain $51 \%\left(\mathrm{R}_{\text {Adj }}^{2}=0.510\right)$ of the variance in MTLP concentration observed in the digestive gland: $\mathrm{Cd}$ and Mn were positively correlated with MT concentration, whereas $\mathrm{Fe}, \mathrm{Ni}$ and $\mathrm{Co}$ were negatively correlated. In the gills, only $\mathrm{Cd}, \mathrm{Mn}$ and $\mathrm{Zn}$ contribute to explaining $50.7 \%\left(\mathrm{R}^{2}\right.$ Adj $\left.=0.507\right)$ of the variance in MTLP, and only Zn presented a negative correlation. At station $\mathrm{P}, \mathrm{Cu}, \mathrm{Cd}$, $\mathrm{Fe}, \mathrm{Ni}$ and Co explain $69.4 \%\left(\mathrm{R}_{\mathrm{Adj}}^{2}=0.694\right)$ of the variance in MTLP (Cu and Ni were negatively correlated) in the digestive gland, whereas in the gills, only Fe contributes, and explains only a small percentage, $18.3 \%,\left(\mathrm{R}^{2}{ }_{\mathrm{Adj}}\right.$ $=0.183$ ) of the variance in MTLP. No strong correlation between MTLP and metals was observed, as indicated by the low values of $\mathrm{R}^{2}{ }_{\text {Adj. }}$. 


\section{DISCUSSION}

Oysters (including Crassostrea angulata) and other species of molluscs are employed in marine environment biomonitoring programmes in many parts of the world, particularly for metal contamination (Rainbow, 1995, O'Connor, 1994). The organism shows a high capacity to accumulate metals in its soft parts, proportionally to metal concentration and bioavailability in the environment (Bryan et al., 1985). It also uses detoxification mechanisms (such as induction of MTLPs) to regulate internal concentration of metals and prevent cellular damage. In this study, the levels of metals in whole body, gills and digestive gland increased during 1998 as the result of metal inputs to the Guadalquivir estuary originating from the Aznalcóllar accident (Gómez-Parra et al., 2000). The maximum levels were observed in 1999, and there was a tendency to decrease or to remain unchanged in subsequent years, depending on the metal (Blasco et al., 2003)

Zinc and copper showed higher accumulation in all tissues analyzed, in agreement with high metal concentrations recorded by Achterberg et al. (1999) in the estuary after the mining spill at Aznalcollar. $C$. angulata shows considerable ability to accumulate $\mathrm{Zn}$ and $\mathrm{Cu}$; this is characteristic of oysters and is due to hemocyanin respiratory pigment (Shulkin et al., 2003; Ruelas-Inzunza et al., 2000). Metal bioaccumulation in oysters shows a temporal variability which can be affected by biotic factors such as abundance of food and weight changes due to biological cycle, particularly reproductive cycle (Raspor et al., 2005; Pytharopolou et al., 2006), and by abiotic factors such as salinity and remobilization of sediment-bound trace metals, which affect both the total dissolved metal concentrations and their bioavailability (Riba, 2005; Bebianno and Serafim, 2003; Ke and Wang, 2001). Tidal changes do not seem affect the metal bioaccumulation and MTLP responses in oysters because the range of concentration found was similar at the two sampling stations despite being subjected to a different tidal regime.

MTLP and some of the metals showed similar seasonal variability. The importance of natural factors in MTLP concentrations was confirmed by multiple regression analysis, which showed that soluble metals only partially (18.3-69.4\%) explain the MTLP variability. Other natural factors can affect MTLP levels.

The values recorded in May 1998 for metals concentrations are almost certainly related to the high environmental metal concentrations due to the mining waste spill. In fact, studies carried out in the oyster $C$. gigas regarding seasonal evolution of metal content in unpolluted areas did not increase in these months (Langston and Spence, 1995). However, differences in metal levels are associated with the reproductive cycle and this influence may be modified depending on the latitude at which the oysters are collected (Frías-Espericueta et al., 1999a; Páez-Osuna et al., 1995).
Metals were differently accumulated in the two target tissues analyzed: $\mathrm{Mn}$ and $\mathrm{Ni}$ were accumulated in gills, and $\mathrm{Fe}, \mathrm{Cd}$ and Co mainly in the digestive gland, whereas $\mathrm{Cu}$ and $\mathrm{Zn}$ showed similar concentrations in both tissues. Similar results were obtained in oyster $C$. iridescens (Frías-Espericueta et al., 1999b) and M. galloprovincialis (Irato et al., 2003; Simkiss and Taylor, 1995). Fisher and Reinfeld (1995) pointed out that the elements associated with particulate material are accumulated in soft tissues like the digestive gland, whereas soluble metals accumulate in the gills: thus, metal accumulation in different tissues are related to the form in which the metal is available in the environment (soluble, particulate, etc.). Gills and digestive gland showed different patterns of MTLP levels: the concentration of proteins in gills was about six times less than in the digestive gland, because the latter is the main organ for detoxification.

In both gills and digestive glands, all the metals were stored mainly in the insoluble fraction, which is in agreement with the biological processes (compartmentalization into lysosomes, granules and membranebound vesicles) proposed by Langston and Spence (1995) and Langston et al. (1998). The insoluble fraction of bioaccumulated metals is the result (at least partly) of the biomineralization into different kinds of granules (Ettajani et al., 2001; George, 1990; Mason and Jenkins, 1995); through this process, metals are no longer active in the intracellular metabolism (Geffard et al. 2005). Another mechanism for controlling intracellular toxicity of metals is binding with cytosolic proteins (MTLP in soluble fraction S2) (Viarengo and Nott, 1993; Roesijadi, 1992). As the cytosolic metal concentration increases, this causes the metals to bind to the heat-stable fraction S2; this may be indirectly related to the increase of total MTLP concentration induced by high intracellular levels of metals (Bonneris et al. 2005), thus confirming the primary role of these proteins in the internal control of metals.

$\mathrm{Cd}, \mathrm{Zn}$ and $\mathrm{Cu}$ are trace metals normally associated with MTLP (Amiard et al., 2006; Mouneyrac et al., 2001). Cd, which is soluble in the $\mathrm{S} 2$ fraction, showed a positive correlation with MTLP concentration in both tissues at the intertidal sampling station (Montijo), whereas there was a negative correlation between soluble $\mathrm{Zn}$ and MTLP concentration in gills at Montijo, and between $\mathrm{Cu}$ concentrations and MTLP in the digestive gland at the subtidal station, Piletas. Occasionally, MTLP may bind to other metals such as Co and Ni (Stegeman et al., 1992). More surprising is the correlation observed with $\mathrm{Fe}$ and Mn, which may be explained by high levels of these metals in the environment after the accident. Transition metals, such as Fe, can cause oxidative stress in marine organisms. Viarengo et al. (1999) observed a small but significant increase in MTLP in digestive gland tissue of mussel after treatment with Fe, suggesting that MTLP plays a role in protecting against Fe-induced oxidative stress. 
Numerous authors have stated that monitoring MTLP in oyster is useful as an indicator of environmental quality (Mouneyrac et al., 2001). However, in most cases the natural variability of MTLP levels in molluscs tends to conceal any changes due to metal pollution. Moreover, a high level of contamination may produce results different from those expected, such as the binding to MTLP by metals ( $\mathrm{Co}, \mathrm{Ni}, \mathrm{Fe}$ and $\mathrm{Mn}$ ) that, in an unpolluted environment, only occasionally bind to these proteins. From the results of this work it is clear that the variations in MTLP levels are not exclusively associated with metal concentration and that other environmental factors could explain a percentage of MTLP variability. Therefore, care is needed in the interpretation of metallothionein levels from field studies.

\section{ACKNOWLEDGEMENTS}

We would like to thank the Junta de Andalucía (Research Plan for Andalusia, RNM306) for funding this research. Chiara Trombini has a fellowship under the Erasmus Programme.

\section{REFERENCES}

Achterberg, E.P., C. Braungart, N.H. Morley, F. Elbaz-Poulichet and M. Leblanc. - 1999. Impact of Los Frailes mine spill on riverine, estuarine and coastal waters in southern Spain. Wat. Res., 33: 3387-3394.

Amiard, J.C., A. Pineau, H.L. Boiteau, C. Metayer and C. AmiardTriquet. - 1987. Application of atomic absorption spectrophotometry using Zeeman effect, to the determination of eight trace elements ( $\mathrm{Ag}, \mathrm{Cd}, \mathrm{Cu}, \mathrm{Mn}, \mathrm{Ni}, \mathrm{Pb}$, and $\mathrm{Se}$ ) in biological materials. Wat. Res., 21:693-697.

Amiard, J.C., C. Amiard-Triquet, S. Barka, J. Pellerin and P.S. Rainbow. - 2006. Metallothioneins in aquatic invertebrates: their role in metal detoxification and their use as biomarkers. Aquat. Toxicol., 76: 160-202.

Bebianno, M.J. and M. A. Serafim. - 2003. Variation of metal and metallothionein concentrations in a natural population of Ruditapes decussatus. Arch. Environ. Contam. Toxicol., 44: 53-66.

Blasco, J., A.M. Arias and V. Sáenz. - 1999. Heavy metals in organisms of the River Guadalquivir estuary: possible incident of the Aznalcollar disaster. Sci. Total Environ., 242: 249-259.

Blasco, J., V. Sáenz, A.M. Arias, R. Gonzáles-Pascual, O. Campana, I. Moreno-Garrido and M. Hampel. - 2003. Efecto del accidente minero sobre los organismos residentes en el estuario del Guadalquivir y en las zonas de la plataforma próxima a su desembocadura. In: Contaminación por metales pesados del estuario del Guadalquivir, pp. 165-203. Convenio octavo del Programa de Investigación del Corredor Verde del Guadiamar. Servicio de Publicaciones. Universidad de Cádiz.

Bonneris, E., A, Giguère, O. Perceval, T. Buronfosse, S. Masson, L. Hare and P.G.C. Campbell. - 2005. Sub-cellular partitioning of metals $(\mathrm{Cd}, \mathrm{Cu}, \mathrm{Zn})$ in the gills of a freshwater bivalve, Pyganodon grandis: role of calcium concretions in metal sequestration. Aquat. Toxicol., 71: 319-334.

Bragigand, V. and B. Berthet. - 2003. Some methodological aspects of metallothionein evaluation. Comp. Biochem. Physiol., A., 134: 55-61

Bryan, G.W., W.J. Langston, L.G. Hummerstone and G.R. Burt. 1985. A guide to the assessment of heavy-metal contamination in estuary using biological indicator. J. Mar. Biol. Ass. U. K., Occasional Publication, pp. 1-92.

Cajaraville, M.P., M. J. Bebianno, J. Blasco, C. Porte, C. Sarasquete and A. Viarengo. -2000 . The use of biomarkers to assess the impact of pollution in coastal environments of the Iberian Peninsula: a practical approach. Sci. Total Environ., 247: 295-311.
Cosson, R.P. - 2000. Bivalves metallothionein as a biomarker of aquatic ecosystem pollution by trace metals: limits and perspectives. Cell. Mol. Biol., 46: 295-309.

Cosson, R.P. and J.C. Amiard. - 2000. Use of metallothioneins as biomarkers of exposure to metals. In: L. Lagadic, T. Caquet, J.C. Amiard and F. Ramade (eds.). Use of biomarkers for environmental Quality Assessment, pp: 79-111. Science Publisher Inc., Enfield.

Dignam, J.D. - 1990. Preparation of Extracts from Higher Eukaryotes. In: M.P. Deutscher (ed.), Guide to Protein Purification., pp. 194-203. Academic Press Inc. San Diego.

Ettajani, H., B. Berthet, J.C. Amiard and L. Chevolot - 2001. Determination of Cadmium partitioning in microalgae and oysters: contribution to the assessment of trophic transfer. Arch. Environ. Contam. Toxicol., 40: 209-221.

Fisher, N.S. and J.R. Reinfeld. - 1995. The trophic transfer of metals in marine system. In: A.Tessier and D.R.Turner (eds.), Metal speciation and bioavailability in aquatic systems. IUPAC Ser. Anal. Physical Chem. Environ. Systems. Vol. 3, pp. 363-406.

Frías-Espericueta, M.G., J.I. Osuna-López and F. Páez-Osuna. 1999a. Gonadal maturation and trace metals in the mangrove oyster Crassostrea corteziensis: seasonal variation. Sci. Total Environ., 231: 115-123.

Frías-Espericueta, M.G., J.I. Osuna-López, G. Sandoval-Salazar and G. López-López. - 1999b. Distribution of trace metals in different tissues in the rock oyster Crassostrea iridescens: seasonal variation. Bull. Environ. Contam. Toxicol. 63: 73-79.

García-Luque, E., J.M. Forja, T.A. DelValls and A. Gómez-Parra. -2003 . The behaviour of heavy metals from the Guadalquivir estuary after the Aznalcollar mining spill: field and laboratory survey. Environ. Monit. Assess., 83: 71-88.

Geffard, A., C. Amiard-Triquet and J.C. Amiard. - 2005. Do seasonal changes affect metallothionein induction by metals in mussels, Mytilus edulis?. Ecotoxicol. Environ. Saf., 61: 209-220.

George, S.G. - 1990. Biochemical and cytological assessment of metal toxicity in marine animals. In: R.W. Furness and P.S. Rainbow (eds.), Heavy metals in the marine environment, pp. 123-142. CRC Press, Boca Raton, FL.

George, S.G. and P.-E. Olsson. - 1994. Metallothioneins as indicators of trace metal pollution. In: J.M. Kramer (ed.), Biomonitoring of coastal waters and estuaries, pp. 151-171. CRC Press, Boca Raton.

Gómez-Parra, A., T.A. DelValls, J.M. Forja, I. Saenz and I. Riba. 2000. Early contamination by heavy metals of the Guadalquivir estuary alter the Aznalcollar mining spill (SW, Spain). Mar. Pollut. Bull., 40(12): 1115-1123.

Grimalt, J.O., M. Ferrer and E. Macpherson. - 1999. The mine tailing accident in Aznalcollar. Sci. Total Environ., 242: 3-11.

Hamza-Chaffay, A., J.C. Amiard and R.P. Cosson. - 1999. Relationship between metallothionein and metals in a natural population of the clam Ruditapes decussatus from the Sfax coast: a nonlinear model using Box-Cox transformation. Comp. Biochem. Physiol., C, 123: 153-163.

Irato, P., G. Santovito, A. Cassini, E. Piccinni and V. Albergoni. - 2003. Metal accumulation and binding protein induction in Mytilus galloprovincialis, Scapharca inaequivalvis, and Tapes philippinarum from the Lagoon of Venice. Arch. Environ. Contam. Toxicol., 44: 476-484.

Ke, C. and W.-X. Wang. - 2001. Bioaccumulation of Cd, Se, Zn in an estuarine oyster (Crassostrea rivularis) and a coastal oyster (Saccostrea glomerata). Aquat. Toxicol., 56: 33-51.

Langston, W.J. and S.K. Spence. - 1995. Biological factors involved in metal concentrations observed in aquatic organisms. In: A. Tessier and D.R. Turner (eds.), Metal speciation and bioavailability in aquatic systems. IUPAC Ser. Anal. Physical Chem. Environ. Systems, Vol. 3, pp. 407-467.

Langston, W.J., M.J. Bebianno and G.R. Burt. - 1998. Metal handling strategies in mollusks. In: W.J. Langston and M.J. Bebianno (eds.), Metal Metabolism in Aquatic Environments, pp. 254-270. Chapman and Hall, London.

Mason, A.Z. and K.D. Jenkins. - 1995. Metal detoxification in Aquatic Organisms. In: A. Tessier and D.R. Turner (eds.), Metal Speciation and Bioavailability in Aquatic System, pp. 480- 582. John Wiley and Sons, New York.

Mouneyrac, C., J.C. Amiard and C. Amiard-Triquet. - 1998. Effects of natural factors (salinity and body weight) on cadmium, 
copper, zinc and metallothionein-like protein levels in resident populations of oysters Crassostrea gigas from a polluted estuary. Mar. Ecol. Prog. Ser., 162: 125-135.

Mouneyrac, C., C. Amiard-Triquet, J.C. Amiard and P.S. Rainbow. - 2001. Comparison of metallothionein concentrations and tissue distribution of trace metals in crabs (Pachygrapsus marmoratus) from a metal-rich estuary, in and out of the reproductive season. Comp. Biochem. Physiol., C, 129: 193-209.

O'Connor, T.P., A.Y. Cantilli and G.G. Lauenstei. - 1994. Monitoring of temporal trends in chemical contamination by the NOAA National Status and trend Mussel Watch Project. In: K.J.M. Kramer (ed.), Biomonitoring of coastal waters and estuaries, pp. 29-45. CRC Press, Boca Raton.

Olafson, R.W. and P.-E. Olsson. - 1991. Electrochemical Detection of Metallothionein. In: J.F. Riordan and B.L. Vallee (eds.), Metallobiochemistry. Part B: metallothionein and related molecules. J.N. Abelson and M.I. Simon (series eds.), Methods in Enzymology Vol. 205, pp. 205-213. Academic Press, London.

Páez-Osuna, F., M.G. Frías-Espericueta and J.I. Osuna-López. -1995 . Trace metal concentrations in relation to season and gonadal maturation in the oyster Crassostrea iridescens. Mar. Environ. Res., 40(1): 19-31.

Pytharopolou, S., E.C. Kouvela, E. Sazakly, M. Leotsinidis and D.L. Kalpaxis. - 2006. Evaluation of the global protein synthesis in Mytilus galloprovincialis in marine pollution monitoring: seasonal variability and correlations with other biomarkers. Aquat. Toxicol., 80: 33-41.

Rainbow, P.S. - 1995. Biomonitoring of heavy metal availability in the marine environment. Mar. Pollut. Bull., 31: 183-192.

Raspor, B., Z. Dragun and M. Erk. - 2005. Examining the suitability of mussel digestive gland as a biomonitoring target organ. Arh. Hig. Rada. Toksikol., 53: 141-149.

Riba, I., J. Blasco, N. Jimenez-Tenorio and T.A. DelValls. - 2005. Heavy metal bioavailability and effects: I. bioaccumulation caused by mining activities in the Gulf of Cádiz (SW, Spain). Chemosphere, 58: 659-669.

Roesijadi, G. - 1992. Metallothioneins in metal regulation and toxicity in aquatic animals. Aquat. Toxicol., 22: 81-114.
Ruelas-Inzunza, J.R. and F. Pàez-Osuna. - 2000. Comparative bioavailability of trace metals using three filter-feeder organisms in a subtropical coastal environment (Southeast Gulf of California). Environ. Pollut., 107: 437-444.

Shulkin, V.M., B.J. Presley and V.I. Kavun. - 2003. Metal concentrations in mussel Crenomytilus grayanus and oyster Crassostera gigas in relation to contamination of ambient sediments. Environ. Int., 29: 493-502.

Silva, C.A.R., P.S. Rainbow, B.D. Smith and Z.L. Santos. - 2001 Biomonitoring of trace metal contamination in the Potengi estuary, Natal (Brazil), using the oyster Crassostrea rhizophorae, a local food source. Water Res., 35: 4072-4078.

Simkiss, K., M.G. Taylor. - 1995. Transport of metal across membranes. In: A.Tessier and D.R. Turner (eds.), Metal Speciation and Bioavailability in Aquatic System, pp. 1-45. John Wiley and Sons, New York.

Stegeman, J.J., M. Brouwer, R.T. Di Giulio, L. Förlin, B.A. Fowler, B.M. Sanders and P.A. Van Veld. - 1992. Molecular Responses to Environmental Contamination: Enzyme and Protein Systems as Indicators of Chemical Exposure and Effect. In: R.J. Hugget, R.A. Kimerle, R.A. Mehrle and H.L. Bergman (eds.), Biomarkers: Biochemical, Physiological, and Histological Markers of Anthropogenic Stress, pp. 235-261. Lewis Publishers, Boca Raton.

Tomaszewska, B. - 2002. Glutathione and thiol metabolism in metal exposed plants. In: M.N.V. Prasad and K. Strzałka (eds.), Physiology and Biochemistry of Metal Toxicity and Tolerance in Plants, pp. 37-58. Kluwer Academic Publisher.

Viarengo, A. and J.A. Nott. - 1993. Mechanisms of heavy metal cation homeostasis in marine invertebrate. Comp. Biochem. Physiol., C, 104(3): 355-372.

Viarengo, A., B. Burlando, M. Cavaletto, B. Marchi, E. Ponzano and J. Blasco. - 1999. Role of metallothionein against oxidative stress in the mussel Mytilus galloprovincialis. Am. J. Physiol. Regul. Integr. Comp. Physiol., 277: 1612-1619.

Received November 1, 2008. Accepted July 26, 2010. Published online November 13, 2010. 